\title{
Edible films based on chayotextle starch and its effect on the shelf life of apples
}

\begin{abstract}
The apple is a climacteric fruit, characterized by having a long post-harvest life in optimal storage conditions, in addition to various nutritional benefits. In Mexico, it has become common to sell apple by piece and ready to be consumed, each piece after being washed and disinfected, is protected with a polyurethane net and a low-density polyethylene plastic film, which contributes to the increase in the generation of solid waste and environmental pollution. The main objective of this work was to evaluate the effectiveness of edible films based on chayotextle starch and pectin with nopal mucilage, to preserve the physicochemical, microbiological and sensory characteristics of apples stored in refrigeration $\left(4-6^{\circ} \mathrm{C}\right)$. Two types of films were made: T1: chayotextle starch (4\%), glycerol (2\%); T2: pectin (1\%), nopal mucilage $(0.5 \%)$, glycerol $(30 \% \mathrm{w} / \mathrm{v})$; These were determined the permeability to water vapor (T1: 1.317x10-12; T2: $8.854 \mathrm{~g} \mathrm{~s}-1 \mathrm{~Pa}-1 \mathrm{~m} \mathrm{-1)}$ and oxygen permeability (T1: 4.444x10-14, T2: $5.87 \mathrm{gm} \mathrm{s}-1 \mathrm{~Pa}-1 \mathrm{~m}-2)$. The shelf-life study in apples showed that both the edible films and the plastic material maintained the physicochemical $(\mathrm{pH})$, sensory, rheological (Hardness) and microbiological (fungi and yeast, mesophilic aerobic and total coliform) characteristics of the apples for 40 days.
\end{abstract}

Keywords: apples, edible films, mucilage, pectin, self-life, starch

\author{
Volume 8 Issue 2 - 202I
}

\author{
Bethsua Mendoza,' Edna María Hernández, ${ }^{2}$ \\ Leyri Desireth Romo,' Apolonio Vargas, ${ }^{3}$ \\ Jorge Alvez Cervantes, ' Ana Guadalupe \\ Estrada Fernández ${ }^{2}$ \\ 'Tecnológico Nacional de México, Instituto Tecnológico Superior \\ del Oriente del Estado de Hidalgo, Mexico \\ ${ }^{2}$ Universidad Politécnica de Pachuca, México \\ ${ }^{3}$ Instituto de Ciencias Agropecuarias, Universidad Autónoma del \\ Estado de Hidalgo, México
}

Correspondence: Bethsua Mendoza, Tecnológico Nacional de México, Instituto Tecnológico Superior del Oriente del Estado de Hidalgo, Carretera Apan - Tepeapulco Km 3.5, Apan, Hidalgo, México, CP.43900,Email bmendoza@itesa.edu.mx

Received: July 17, 2019 | Published: March 10, 2021

\section{Introduction}

At present, the growing demand by consumers towards foods that are easy to prepare, safe, natural, functional and that are also packaged with biodegradable containers, has motivated the development of new technologies for the processing and preservation of food whose main objective It is the inactivation of enzymes and microorganisms that lead to the deterioration of the product, without adverse consequences, sensory and nutritional quality. ${ }^{1}$ In the case of fruits and vegetables, it is very important to take into account the nutritional losses due to dehydration and effects on their appearance from the moment from harvesting to consumption. ${ }^{2}$ In this sense, the development of new and innovative biomaterials as food protectants has taken on great relevance, such is the case of edible films and coatings that emerge as a promising alternative to ensure quality through of the food chain. ${ }^{1}$

Edible films should function as a selective barrier to the transfer of moisture and gases, in addition to avoiding the oxidation of lipids and the loss of volatile compounds responsible for the aromas and flavors of certain foods. They must be formulated with food grade compounds and also meet relatively low production costs. Materials tested for film formation include proteins, polysaccharides and lipids. Among the main proteins are gelatin, collagen and some proteins of vegetable origin such as soy and corn. The most studied polysaccharides include cellulose and its derivatives, carrageenans, gums, pectin, starch and alginates; while the most commonly used lipids are waxes, triglycerides and some fatty acids. ${ }^{3}$ Chayote (Sechium edule Sw.) tubers are perennial climbing plants native to Mexico. This plant produces a fruit similar to squash that may be grown as a food crop. Chayote plants also produce tubers that are rich in starch to provide a potential local or regional source of starch. ${ }^{4} 25.8 \%$ of its total composition is of solids of which $59 \%$ is starch, and can be extracted with a purity of approximately $90 \%$, reason why it is considered an unconventional source of starch, feasible for the elaboration of edible films or other applications. ${ }^{5}$ On the other hand, the nopal mucilage is a heteropolysaccharide composed of D-galactose, L-arabinose. D-xylose and L-rhamnose, although it does not have the property of forming films, its incorporation into the filmogenic solutions, can bring benefits in the mechanical and permeability properties of these materials. Some research reports that the use of chayotextle starch confers advantages over other biopolymers in the production of films, among them are lower solubility and permeability to water vapor, which favors the stability of the material and the shelf life of the packaged product. The objective of the present work is to apply the edible films of cayotextle and pectin-mucilage of nopal, to evaluate the impact on the shelf life of apples and to compare with the use of synthetic materials.

\section{Materials and methods}

\section{Extraction of chayotexlte starch}

The tuber was washed, cut and ground in an industrial blender (Osterizer). The mixture was decanted after 30 minutes of rest, the supernatant was mixed with distilled water in a 2:1 ratio (pulp: water) and left to rest for 30 minutes, finally the mixture was filtered using a $250 \mu \mathrm{m}$ mesh. This procedure was repeated until the filtrate water was completely clear. The mixtures resulting from the washings were placed in a centrifuge (LEC brand) at 10,000 rpm for 20 minutes, to remove the proteins, the sample was dried in a SHEL LAB 1380FX oven at $40^{\circ} \mathrm{C}$ for 24 hours and crushed using a mill portable electric (Gater 230v 300w), the powder was stored in hermetically sealed polyethylene bags.

\section{Extraction of cactus mucilage}

Cladodes from 1 to 3 years of age collected in the municipality of Apan, Hidalgo, Mexico were used. The use of cladodes that had physical damage or pests was avoided. Spines were removed from each piece and washed to avoid the presence of any foreign matter. Subsequently, the nopales were ground with water in a 1:4 ratio 
(nopal:water) and boiled for 30 minutes, the resulting mixture was filtered and ethanol was added ( 1 part of the mixture with 1.5 parts of ethanol). To easily separate the mucilage, it was left freezing for 24 hours, the precipitate was preserved, and then dried at $60^{\circ} \mathrm{C}$ for 24 hours, finally the solid was crushed until obtaining a fine powder.

\section{Edible films based on chayotextle starch}

$4 \mathrm{~g}$ of chayotextle starch and $2 \mathrm{~g}$ of glycerol (CIVEQ) were dissolved in distilled water. The first step is to add the glycerol to $80 \%$ of the total water to be used, it is placed in a water bath at $60^{\circ} \mathrm{C}$ maintaining a stirring speed of $100 \mathrm{rpm}$, then the starch and the rest of the water are added, the speed of stirring and temperature were increased to $125 \mathrm{rpm}$ and $85^{\circ} \mathrm{C}$. Finally, the mixture was placed in molds and the water was evaporated at $50^{\circ} \mathrm{C}$ for 24 hours.

\section{Edible films based on pectin-mucilage}

A mixture was made with $0.5 \%$ mucilage, $1 \%$ pectin (P9135 Sigma-Aldrich) and 30\% (w/v) glycerol (Glycerin A.C.S. Meyer) in distilled water. The film was cast by casting and dried at $50^{\circ} \mathrm{C}$ for 24 hours.

\section{Oxygen permeability}

The test was carried out on a VAC 2 Lab think equipment to measure gas permeability in plastic films. This equipment measures the transfer of permeating gas through a film according to the manometric principle ASTM D1434-32, 1998. Prior to analysis, the films were cut into $9.3 \mathrm{~cm}$ diameter circles and placed in a desiccator with relative humidity $55 \%$ for 48 hours.

\section{Water vapor permeability}

Water vapor permeability was determined gravimetrically using the standard method of ASTM E96-80 1989. The films were cut into 7 $\mathrm{cm}$ diameter circles and placed in a desiccator with relative humidity of $57 \%$ for 48 hours. $30 \mathrm{~g}$ of dry silica were added to aluminum caps and hermetically sealed with the films. Finally, the capsules were placed in a desiccator with saturated $\mathrm{NaCl}$ solution maintaining a $\mathrm{RH}$ of $75 \%$. Capsule weights were recorded every hour for 8 hours.

\section{Shelf-life study}

Yellow apples purchased from a local self-service store were used. They were washed and disinfected using a $1 \%$ sodium hypochlorite solution for 10 minutes. Subsequently, under accepting conditions, each apple was wrapped with films, taking as control treatment apples covered with low-density polyethylene plastic film. T1: apples covered with chayotextle starch film (P-C), T2: apples covered with pectin-mucilage film (P-PM), T3: apples covered with plastic film (P-P) and T4: apples without coating. All treatments were stored in refrigeration $\left(4-6{ }^{\circ} \mathrm{C}\right)$ for 40 days. Samples were taken every 10 days for microbiological, sensory, rheological and $\mathrm{pH}$ analysis.

\section{Microbiological analysis}

The microbial growth in apples was monitored during 40 days of storage. The presence of aerobic mesophilic organisms was quantified according to the NOM-092-SSA1-1994 standard, fungi and yeasts (NOM-111-SSA1-1994) and total coliforms (NOM-113-SSA1-1994).

\section{Sensory evaluation}

A triangular test was applied with a panel of 30 untrained judges. The objective of this test was to evaluate the sensory changes during the storage time (taste, color, smell and texture), in comparison with apples covered with plastic film.

\section{pH \& texture}

To measure the $\mathrm{pH}$, a puncture potentiometer (Tester PHT 5 FOOD) was used, measuring in three different areas of the apple. The penetration force was measured for each treatment and during the entire storage time. A Texture Anazer Brookfield texturometer with a $25 \mathrm{~kg}$ load cell and a $2 \mathrm{~mm}$ diameter and $20 \mathrm{~mm}$ long metal probe was used.

\section{Statistical analysis}

All analyzes were performed in triplicate, the mean and standard deviation were reported for each treatment. The data were analyzed using one-way analysis of variance, taking the type of film as the independent variable and the permeability to water vapor and the permeability to oxygen as the response variable. The $\mathrm{pH}$ and hardness data were analyzed with a factorial design taking 3 levels of factor A (film type) and 5 levels of factor B (days of storage). The statistical program Sigma Plot 12.0 and 95\% reliability were used.

\section{Results}

\section{Oxygen permeability}

Table 1 shows the results obtained for oxygen permeability, which indicate that there are no statistically significant differences between the three treatments, however, it can be seen that the pectin-nopal mucilage films present the highest value.

Table I Results of oxygen permeability $\left(\mathrm{PO}_{2}\right)$ of films based on chayotextle starch (P-C), pectin-mucilage (P-PM) and plastic film (P-P)

\begin{tabular}{ll}
\hline Treatment & PO $_{2}\left(\mathbf{g ~ m ~ s}^{-1} \mathbf{P a}^{-} \mathbf{I ~ m}^{-2}\right)$ \\
\hline TI $(\mathrm{P}-\mathrm{C})$ & $4.44 \times 10^{-14} \pm 1.255 \times 10^{-14 a}$ \\
T2 $(\mathrm{P}-\mathrm{PM})$ & $5.87 \times 10^{-14} \pm 1.68 \times 10^{-14 a}$ \\
T3 $(\mathrm{P}-\mathrm{P})$ & $1.95 \times 10^{-14} \pm 2.36 \times 10^{-14} \mathrm{a}$
\end{tabular}

${ }^{a b}$ different letters in each column indicate statistically significant differences. One-way ANOVA and comparison of means by Tukey $(P<0.05)$

\section{Permeability to water vapor}

It is demonstrated that the water vapor permeability is the same in the three types of packaging materials used, since the statistical analysis showed that there are no statistically significant differences between the three treatments, however, the highest values were obtained for films pectin-mucilage base of nopal (Table 2).

Table 2 Results of water vapor permeability (PVA) of films based on chayotextle starch (P-C), pectin-mucilage (P-PM) and plastic film (P-P)

\begin{tabular}{ll}
\hline Treatment & PVA $\left(\mathrm{g} \mathrm{s}^{-1} \mathbf{P a}^{-1} \mathbf{~ m}^{-1}\right)$ \\
\hline TI $(P-C)$ & $1.317 \times 10-12 \pm 2.069 \times 10^{-13} \mathrm{a}$ \\
T2 $(P-P M)$ & $8.854 \times 10-12 \pm 3.424 \times 10^{-13} \mathrm{a}$ \\
T3 (P-P) & $6.34 \times 10-12 \pm 1.076 \times 10^{-13} \mathrm{a}$ \\
\hline
\end{tabular}

ab different letters in each column indicate statistically significant differences. One-way ANOVA and comparison of means by Tukey $(P<0.05)$

\section{Microbiological analysis}

The aerobic mesophilic organisms and total coliforms did not proliferate in the sample during the first 30 days, on the contrary at 20 days the proliferation of fungi and yeasts began, the count of fungi and yeasts, at 20 days it showed an increase having for T1 (PC ): 22, 
T2 (P -PM): 37, T3 (PP): 12 and T4 (C): 23 CFU / g of food (Table 3 ). In general, it can be observed that the microbiological quality in all the treatments remained within the norm, however, apples packed with chayotextle starch (T3 AC) presented fewer microorganisms compared to those packed with pectin film- mucilage. Apples stored in refrigeration without film (T4 C), presented the highest number of microorganisms after 40 days of storage.

Table 3 Results of microbiological analysis of apples packed with biodegradable films and stored in refrigeration (CFU / $g$ of apple)

\begin{tabular}{|c|c|c|c|c|c|c|}
\hline \multirow[t]{2}{*}{ Parameter } & \multirow[t]{2}{*}{ Treatment } & \multicolumn{2}{|c|}{ Time (Days) } & \multirow[b]{2}{*}{20} & \multirow[b]{2}{*}{30} & \multirow[b]{2}{*}{40} \\
\hline & & 0 & 10 & & & \\
\hline \multirow[t]{4}{*}{ Standard account } & $\mathrm{TI}(\mathrm{P}-\mathrm{C})$ & ND & ND & ND & ND & 89 \\
\hline & T2 (P-PM) & ND & ND & ND & ND & 103 \\
\hline & T3 (P-P) & ND & ND & ND & ND & 51 \\
\hline & $\mathrm{T} 4(\mathrm{C})$ & ND & ND & ND & ND & 400 \\
\hline \multirow[t]{4}{*}{ Total coliforms } & $\mathrm{TI}(\mathrm{P}-\mathrm{C})$ & ND & ND & ND & ND & ND \\
\hline & T2 (P-PM) & ND & ND & ND & ND & ND \\
\hline & T3 (P-P) & ND & ND & ND & ND & ND \\
\hline & $\mathrm{T} 4(\mathrm{C})$ & ND & ND & ND & ND & ND \\
\hline \multirow[t]{4}{*}{ Fungi and yeasts } & $\mathrm{TI}(\mathrm{P}-\mathrm{C})$ & ND & ND & 22 & 87 & 300 \\
\hline & T2 (P-PM) & ND & ND & 37 & 184 & 500 \\
\hline & T3 (P-P) & ND & ND & 12 & 96 & 166 \\
\hline & $\mathrm{T} 4(\mathrm{C})$ & ND & ND & 23 & 160 & 2300 \\
\hline
\end{tabular}

ND, not detectable

\section{Sensory evaluation}

Table 4 shows the results of the triangular test on all storage days. For each day of analysis, the number of judges who answered correctly and the number of judges who did not are shown. In general, the number of judges who answered correctly is lower in all cases.

\section{$\mathrm{pH}$}

Table 5 shows the $\mathrm{pH}$ results. The values ranged between 4.2 and 4.9 , the statistical analysis revealed that the type of film and the storage time did not cause a statistically significant effect on the $\mathrm{pH}$ values, remaining practically constant during the storage period.

Table 4 Triangular test results for apples packed with polymeric films and stored in refrigeration

\begin{tabular}{|c|c|c|c|c|c|}
\hline & & \multicolumn{2}{|l|}{ T3 (P-P) \& T I (P-C) } & \multicolumn{2}{|l|}{ T3 (P-P) \& T2 (P-PM) } \\
\hline & \multicolumn{5}{|c|}{ Total judges } \\
\hline Day & & $\begin{array}{l}\text { Judges who answered } \\
\text { correctly }\end{array}$ & $\begin{array}{l}\text { Judges who did not } \\
\text { answer correctly }\end{array}$ & $\begin{array}{l}\text { Judges who answered } \\
\text { correctly }\end{array}$ & $\begin{array}{l}\text { Judges who did not } \\
\text { answer correctly }\end{array}$ \\
\hline 10 & & 13 & 17 & 9 & 21 \\
\hline 20 & & II & 19 & 15 & 15 \\
\hline 30 & 30 & 12 & 18 & 12 & 18 \\
\hline 40 & & 9 & 21 & 13 & 17 \\
\hline
\end{tabular}

Table $\mathbf{5}$ Value of $\mathrm{pH}$ of apples packed with biopolymeric films and packed in refrigeration

\begin{tabular}{|c|c|c|c|c|c|}
\hline \multirow[t]{2}{*}{ Treatment } & \multicolumn{5}{|c|}{ Storage days } \\
\hline & 0 & 10 & 20 & 30 & 40 \\
\hline TI (P-M) & $4.72 \pm 0.1 \mathrm{Ia}$ & $4.69 \pm 0.16 a$ & $4.22 \pm 0.13 a$ & $4.44 \pm 0.0 \mathrm{la}$ & $4.78 \pm 0.37 a$ \\
\hline T2 (P-P) & $4.72 \pm 0.1 \mathrm{Ia}$ & $4.98 \pm 0.02 a$ & $4.75 \pm 0.2 \mathrm{la}$ & $4.2 \pm 0.06 a$ & $4.34 \pm 0.05 a$ \\
\hline T3 (A-C) & $4.72 \pm 0.1 \mathrm{la}$ & $4.7 I \pm 0.13 a$ & $4.32 \pm 0.0 \mathrm{la}$ & $4.45 \pm 0.27 a$ & $4.38 \pm 0.04 a$ \\
\hline
\end{tabular}

$\mathrm{a}, \mathrm{b}, \mathrm{c}$ different letters in rows and in columns represent statistically significant differences. Analysis of variance with factorial design, followed by comparison of means by Tukey $(P<0.05)$ 


\section{Texture analysis}

The results show that the type of packaging does not cause statistically significant changes in the texture of the apples, on the contrary, the storage time does affect this parameter, the most significant change was observed between day 0 and 10 of storage, showing a reduction of hardness by almost half of the initial value, however, it remained constant up to 40 days of storage (Table 6).

Table 6 Hardness results for apples packed with biopolymer films stored in refrigeration

\begin{tabular}{llllll}
\hline Treatment & \multicolumn{5}{l}{ Storage days } \\
\hline & 0 & 10 & 20 & 30 & 40 \\
\hline TI (P-M) & $8.45 \pm 3.17 \mathrm{a}$ & $4.71 \pm 0.86 \mathrm{~b}$ & $4.18 \pm 0.03 \mathrm{~b}$ & $5.88 \pm 0.18 \mathrm{~b}$ & $2.55 \pm 0.06 \mathrm{~b}$ \\
T2 (P-P) & $8.45 \pm 3.18 \mathrm{a}$ & $5.46 \pm 0.65 \mathrm{~b}$ & $5.88 \pm 1.29 \mathrm{~b}$ & $5.29 \pm 1.38 \mathrm{~b}$ & $5.11 \pm 1.18 \mathrm{~b}$ \\
$\mathrm{~T} 3$ (A-C) & $8.45 \pm 3.18 \mathrm{a}$ & $4.92 \pm 1.27 \mathrm{~b}$ & $4.78 \pm 0.95 \mathrm{~b}$ & $4.4 \pm 2.23 \mathrm{~b}$ & $4.99 \pm 0.1 \mathrm{~b}$ \\
\hline
\end{tabular}

a,b c different letters in columns and rows represent statistically significant differences. ANOVA with factorial design, followed by comparison of means by Tukey $(\mathrm{P}<0.05)$

\section{Discussions}

The permeability to gases (water vapor and oxygen) in food packaging materials is one of the most important characteristics. The increase in permeability is considered to be due to the solubility and absorption of gases in the water retained by the polymer. A packaging material must have the characteristic of functioning as a barrier to gases, mainly oxygen and carbon dioxide. Due to the oxidation reactions caused by oxygen, for some foods it is important that the films have low oxygen permeability. ${ }^{6} \mathrm{PVA}$ results are higher compared to PVA values reported for chitosan-methylcellulose, chitosan, and methylcellulose films, 9.14 x 10-13, 1.90 x 10-13 g. s-1 Pa-1.m-1, respectively. $^{7}$

Cassava starch films of various species have an average PVA of $7.39 \times 10-11$ g. s-1. Pa-1.m-1 low values with respect to that reported in this research, ${ }^{8}$ in the same way the results reported for high amylose corn starch films, rice starch / chitosan (2:1), 2\% tapioca starch, HPMC (hydroxypropylmethylcellulose), HPMC/20\% beeswax: stearic acid and methylcellulose. ${ }^{7}$ These variations in permeability are mainly due to the structural characteristics of the polymer (polarity), and the formulation of the film, for example The greater the amount of plasticizer, the more permeable the film will be to water vapor. The plasticizer reduces the intermolecular forces between the polymer chains, giving a greater molecular mobility.

The effectiveness of an edible coating on fruits depends on the control of humidity and the ability of the matrix to maintain compounds of different functionality (plasticizers, antimicrobials, antioxidants, flavors and odors) because the loss of the components affects the thickness of the coating and the water solubility. ${ }^{9}$ The RM 615-2003 standard, for semi-processed fresh fruits and vegetables, specifies that the maximum permitted content of aerobic mesophiles must be 8 logarithms. In an analysis carried out on Starkimson apples and Golden apples, $21 \mathrm{CFU} / \mathrm{g}$ of fungi and yeasts were reported, in addition to the presence of Salmonella sp, E. coli, and no total coliform count was detected. ${ }^{10}$ Since the values of the present investigation are lower, it means that the biopolymeric films of chayotextle starch and pectin-mucilage are suitable for preserving the microbiological quality of apples for up to 40 days.

In the results of the sensory evaluation, it is important to remember that the number of judges with the correct answer to establish a statistically significant difference between the samples is $15 .{ }^{11}$ Therefore, it can be said that the samples packed with chayotextle starch and pectin films -mucilage have the same organoleptic characteristics as those apples that were stored with plastic film. Although no statistically significant differences were declared, the judges who managed to detect them mentioned that the apples covered with plastic film had a firmer texture and a sweeter taste.

The $\mathrm{pH}$ results agree with that reported by Delhom ${ }^{12}$ who mentions values between 3 and 5. On the other hand, Díaz ${ }^{13}$ reports values between 3.5 and 3.89 for different varieties of apples (Fujion, G.Smoothie, Opal, Story), however, it is important to note that the maturity stage was lower than that of the present work. When preserving food, it is important to take into account the $\mathrm{pH}$ values since this is a parameter that directly influences the growth of microorganisms, that is, at a $\mathrm{pH}$ closer to neutrality, the growth of bacteria, fungi and yeasts is favored. On the other hand, it is also indicative of the state of maturity and freshness of fruits and vegetables, the lower the $\mathrm{pH}$, the lower the state of maturity. Specifically, for apples, tartaric acid contributes more significantly to the $\mathrm{pH}$ value of the fruit.

Hardness is the most important attribute of mechanical texture in food; In the case of meat products, fruits and dairy products such as cheese, together with taste and appearance, are the characteristics on which the consumer bases his decision when ingesting, such as, for example, a piece of meat from a specific animal species to then make a sensory comparison of others. In fruits, determines the degree of maturation that is found. As for the other texture parameters, they generally determine the rheological state that predominates in the food.

For freshly cut apples, values of $10 \mathrm{~kg} / \mathrm{m}^{2}$ are reported, ${ }^{13}$ the results of the present work are lower, because the apples with which they were worked were acquired from a supermarket, which represents a storage period prior to the analysis.

\section{Conclusion}

According to the results obtained in the present work, it can be said that the films based on chayotextle and pectin-mucilage of cactus, can be an excellent option to maintain shelf life for up to 40 days as they contribute to maintain the characteristics, microbiological and sensorial of the apples in the same way as a plastic film, which represents an excellent option to reduce the use of synthetic materials and thus reduce environmental pollution. Finally, it is important to mention that in general, pectin-mucilage films of cactus show a greater flexibility than those of chayotextle, which favors its handling and adherence to the product.

\section{Acknowledgments}

The authors would like to thank the anonymous reviewers for their valuable comments on this article, as well as the collaboration of the academic group of agro-alimentary biotechnology. 


\section{Conflicts of interest}

The author declares that no conflict of interest.

\section{Funding}

None.

\section{References}

1. De Ancos B, González-Peña D, Colina-Coca C, et al. Use of edible films/ coatings on IV and V range products. Rev Iber Tecnolgía Postchosecha. 2015;16(1):8-17.

2. Morales NB, Aycaro E, Rodríguez R. Coatings for fruits. Revista Alimentos Hoy. 2015;23(35):20-32.

3. Domínguez-Courtney MF, Jiménez-Munguía MT. Edible films formulated with polysaccharides: properties and applications. Selected Food Engineering Topics. 2012;6(2):110-121.

4. Cotonieto-Morales MB, Palma-Rodríguez HM, Chavarría-Hernández N, et al. Partial characterization of chayotextle starch composites with added polyvinyl alcohol. Starch/Stärke. 2015;67:355-364.

5. Hernández JP, Agama E, González RA, et al. Isolation and characterization of Mexican chayote tuber (Sechium edule Sw.) Starch. 2011;63:32-41.
6. Fontes LB, Ramos KK, Sivi TC, et al. Biodegradable edible films from renewable sources-potential for their application in fried foods. American Journal of Food Technology. 2011;6(7):555-567.

7. Solís RS. Preparation and characterization of edible films made with hydroxypropylmethylcellulose (HPMC). Tesis de doctorado. Universidad Autónoma del Estado de México. 2016.

8. Joaqui DF, Villada HS. Optical Properties and wáter vapor permeability in films produced from starch. Biotecnología en el Sector Agropecuario y Agroindustrial. 2013;2:59-68.

9. Vázquez M, Guerrero J. Coating fruits with biofilms. Selected Food Engineering Topics. 2013;7(2):5-14.

10. Raggio M, Moro R. Use of the pressure chamber and thermocouple psychrometers in the determination of water relations in plant tissues. International Journal of Experimental Botany. 2008;77:5-17.

11. Anzaldúa-Morales A. Sensory evaluation of food in theory and practice. Zaragoza: Editorial Acribia, S.A; 1994.

12. Delhom MJ. The quality of apples and pears. Ministry of Agriculture, Fisheries and Food. Madrid: Publicaciones de extensión agraria; 1985.

13. Díaz F. Physicochemical characterization of speckled apple varieties (venturiaina equalis (cke.) Winter) and sensory enhancement. Tesis de licenciatura no publicada. Universidad Politécnica de Catalunya Barcelona Tech. Barcelona, España. 2015. 